Archived version from NCDOCKS Institutional Repository http://libres.uncg.edu/ir/asu/

\title{
Appalachlyan
}

B O O N E, NORT H CAROLIN A

\section{It's The Nature Of The Work: Examining Behavior-Based Sources Of Work-Family Conflict Across Occupations}

\author{
By: Erich C. Dierdorff and J. Kemp Ellington
}

\begin{abstract}
The consequences of work-family conflict for both individuals and organizations have been well documented, and the various sources of such conflict have received substantial attention. However, the vast majority of extant research has focused on only time- and strain-based sources, largely neglecting behavior-based sources.

Integrating two nationally representative databases, the authors examine 3 behavior-based antecedents of workfamily conflict linked specifically to occupational work role requirements (interdependence, responsibility for others, and interpersonal conflict). Results from multilevel analysis indicate that significant variance in workfamily conflict is attributable to the occupation in which someone works. Interdependence and responsibility for others predict work-family conflict, even after controlling for several time- and strain-based sources.
\end{abstract}

Dierdorff, E. C., \& Ellington, J. K. (2008). It's the nature of the work: Examining behavior-based sources of work-family conflict across occupations. Journal of Applied Psychology, 93(4), 883-892.

http://dx.doi.org/10.1037/0021-9010.93.4.883. Publisher version of record available at: http://psycnet.apa.org/ record/2008-09088-012 


\title{
It's the Nature of the Work: Examining Behavior-Based Sources of Work-Family Conflict Across Occupations
}

\author{
Erich C. Dierdorff \\ DePaul University
}

\author{
J. Kemp Ellington \\ Illinois Institute of Technology
}

\begin{abstract}
The consequences of work-family conflict for both individuals and organizations have been well documented, and the various sources of such conflict have received substantial attention. However, the vast majority of extant research has focused on only time- and strain-based sources, largely neglecting behavior-based sources. Integrating two nationally representative databases, the authors examine 3 behavior-based antecedents of work-family conflict linked specifically to occupational work role requirements (interdependence, responsibility for others, and interpersonal conflict). Results from multilevel analysis indicate that significant variance in work-family conflict is attributable to the occupation in which someone works. Interdependence and responsibility for others predict work-family conflict, even after controlling for several time- and strain-based sources.
\end{abstract}

Keywords: work-family conflict, work role requirements, O*NET, General Social Survey

Conflict between work and nonwork roles has been long recognized as a potent source of strain and stress (Kahn, Wolfe, Quinn, Snoek, \& Rosenthal, 1964). One salient form of inter-role conflict is that between work and family roles, which has been defined as conflict stemming from "role pressures from the work and family domains [that] are mutually incompatible in some respect" (Greenhaus \& Beutell, 1985, p. 77). More than two decades of literature has noted the significant impact of work-family conflict on a variety of individual outcomes, including job burnout (Pleck, Staines, \& Lang, 1980), job dissatisfaction (Bacharach, Bamberger, \& Conely, 1991; Bedeian, Burke, \& Moffett, 1988), turnover intentions (Burke, 1988), absenteeism (Goff, Mount, \& Jamison, 1990), and health issues, such as depression and somatic complaints (Frone, Russell, \& Cooper, 1992; Thomas \& Ganster, 1995).

In addition to portraying the consequences of work-family conflict, prior theoretical and empirical work has delineated the nature and antecedents of work-family conflict. This literature conceptualizes work-family conflict as bidirectional in nature, such that it may arise when the demands of one's work role interfere with one's family role or when the demands of family interfere with performance of the work role (Gutek, Searle, \&

Erich C. Dierdorff, Department of Management, Kellstadt Graduate School of Business, DePaul University; J. Kemp Ellington, Institute of Psychology, Illinois Institute of Technology.

We thank Peggy Kim for her valuable assistance in conducting this research. An earlier version of this manuscript was presented at the 67th annual meeting of the Academy of Management, Philadelphia, PA, August 2007.

Correspondence concerning this article should be addressed to Erich C. Dierdorff, Kellstadt Graduate School of Business, Department of Management, DePaul University, 1 East Jackson Boulevard, Chicago, IL 606042287. E-mail: edierdor@depaul.edu
Klepa, 1991; Pleck et al., 1980). Antecedents of work-family conflict have been theoretically grouped into three broad categories that include time-based, strain-based, and behavior-based sources (Greenhaus \& Beutell, 1985). In general, time-based sources stem from time pressures of one role encroaching on the fulfillment of expectations and demands of another role. Strainbased sources occur when strain or stress (e.g., anxiety, fatigue, etc.) existing in one role make it difficult to comply with the demands of another role. Behavior-based sources arise when behaviors demanded in one role interfere with the performance of another role.

Substantial research has offered evidence of time-based (e.g., Aryee, 1992; Carlson \& Frone, 2003; Greenhaus, Bedeian, \& Mossholder, 1987; O’Driscoll, Ilgen, \& Hildreth, 1992) and strainbased (e.g., Boyar, Maertz, Pearson, \& Keough, 2003; Frye \& Breaugh, 2004; Voydanoff, 1988; Warren \& Johnson, 1995) sources of work-family conflict, as these categories have received the most empirical attention (O'Driscoll, Brough, \& Kalliath, 2006). Focused examinations of behavior-based sources of workfamily conflict, however, have been notably absent from the literature, a paucity illustrated in recent meta-analytic work (e.g., Ford, Heinen, \& Langkamer, 2007). Thus, we sought to examine several behavior-based antecedents of work-family conflict. To accomplish this purpose, we used data from two nationally representative databases: the General Social Survey and the U.S. Department of Labor's Occupational Information Network (O*NET).

\section{Theoretical Framework}

The theoretical backdrop for much of the work-family conflict literature has derived from the tenets of role theory, in which conflict is typified by the co-occurrence of competing pressures from an individual's multiple roles that make enacting these roles somehow more difficult (Kahn et al., 1964). Conflict theory posits 
that roles are enacted in separate environments entailing distinct norms and requirements (Evans \& Bartolome, 1984). These disparities often necessitate the sacrifice of meeting expectations for one role to enact the other role (Zedeck \& Mosier, 1990). Adding to the potential strain of balancing multiple roles is the fact that individuals have finite personal resources (e.g., attention, energy, etc.) to transfer from one role to another (Edwards \& Rothbard, 2000). Thus, enacting multiple roles can drain these resources, negatively impact role enactment, and cause stress (Aryee, Srinivas, \& Tan, 2005). To reduce this stress, individuals are often forced to make concessions in performing one role over another. In the context of work and family roles, such interference can cause inter-role conflict (Greenhaus \& Beutell, 1985).

The general demands of a particular role refer to the various requirements, expectations, and commitments associated with that social position (Netemeyer, Boles, \& McMurrian, 1996). In work organizations, roles serve the important function of coordinating and integrating behavior of individual members (Biddle, 1979; Katz \& Kahn, 1978). Demands associated with these work roles are communicated by multiple sources of social information (Kahn et al., 1964). Sources of role-related information comprise an individual's role set and span both formal (e.g., job descriptions, boss, etc.) and informal (e.g., coworkers, customers, etc.) sources. Thus, a work role set consists of any person, or any "attached" role for that matter, which consistently makes legitimate demands on the focal role holder (Beehr, 1995).

\section{Work Role Set Relationships and Behavior-Based Conflict}

Elements of the social environment, such as interpersonal interactions, have long been theorized as a central force influencing work-related stress (French \& Kahn, 1962; Katz \& Kahn, 1978). Because the role set will include persons and other work roles that are affiliated with a given work role, these sources of role-related information will influence the various demand expectations comprising that work role. Not only will interpersonal interactions provide social information that shapes an individual's work role expectations, but these interactions will also necessitate particular behavioral requirements. In this sense, these social elements provide important role-related information that both circumscribes and adds to the behavioral requirements of work roles. Further, these behavioral requirements could manifest as behavior-based sources of work-family conflict. For example, certain job demands (e.g., engaging in personal contact and communicating judgments) often increase role conflict in general (Shaw \& Riskind, 1983).

It is important to note that behavior-based conflict does not necessarily involve conflicting demands from multiple roles but simply entails some sort of behavioral interference when performing different roles (Edwards \& Rothbard, 2000). That is, to the extent that requisite work behaviors interfere with role performance in the family domain, they can be viewed as work-related sources of behavior-based conflict. Spillover theory describes such interference as effects stemming from when "behavior developed in one domain influences behavior in the other domain, with the added condition that the transferred behavior inhibits role performance in the latter domain" (Edwards \& Rothbard, 2000, p. 182). Moreover, interference from spillover effects can inhibit multiple role performance by exhausting an individual's psychological and physiological resources (Aryee et al., 2005; Zedeck \& Mosier, 1990).

\section{Occupational Differences in Behavior-Based Conflict}

The extent to which interpersonal interactions comprise work roles largely depends on occupational membership. By definition, work and worker requirements significantly vary across occupations (Dunnette, 1999). Therefore, occupational membership can serve as a boundary condition for differences in behavior-based sources of work-family conflict, vis-à-vis the specific differences in behavioral requirements directly inherent to occupations. As Johns (2006) noted, "knowing someone's occupation often permits reasonable inferences about his or her task, social, and physical environment at work, which, in turn, can be used to predict behavior and attitudes" (p. 393). Further, through the work structures they create, occupations partly constrain how individuals manage boundaries between work and family roles (Kossek, Lautsch, \& Eaton, 2005; Olson-Buchanan \& Boswell, 2006). Recognizing occupational differences, some of the earliest workfamily conflict literature noted the stress caused by duties associated with managerial work (Kahn et al., 1964).

It is important to recognize that examining differences in workfamily conflict across occupations naturally involves varying levels of analysis, as individuals are "nested" within occupations. One way to conceptualize occupations in this manner is by considering the distinct behavioral contexts that occupations generate. These behavioral contexts are delineated by the variety of situational opportunities and constraints commensurate to an occupation (Johns, 2006). As such, individuals within a given occupation engage role performance within very similar behavioral contexts, especially in relation to the behavioral requirements of the occupational role (Dierdorff \& Morgeson, 2007). The critical implication for investigating behavior-based sources of work-family conflict using occupational requirements is that such examinations necessarily entail analyzing variables from multiple levels (i.e., those from the individual level and from the occupational level). ${ }^{1}$

\section{Hypothesis Development}

Differences in behavioral requirements are linked to occupational membership and, thus, occupations can be expected to meaningfully differ with respect to various psychosocial features (Strong, Jeanneret, McPhail, Blakley, \& D’Egidio, 1999). One central aspect of the psychosocial work environment is the nature of interpersonal interactions (Evans, Johansson, \& Carrere, 1994). Such interactions encompass the types of interpersonal relationships an individual must assume as part of his or her work role enactment and include the extent to which performance (a) requires interdependence with other individuals or work roles, (b) requires different amounts of responsibility for other workers, and (c) is associated with different amounts of conflict encountered as

\footnotetext{
${ }^{1}$ This discussion should not be construed as meaning that behaviorbased antecedents of work-family conflict must be treated at the occupational level. Rather, we intend to convey that when individual-level perceptions of work-family conflict are examined for behavior-based sources defined by occupational requirements, such analysis directly involves variables from multiple levels.
} 
part of the work role (Strong et al., 1999). These types of interpersonal relationships are also influential factors related to work stress and behavior (McGrath, 1976).

\section{Interdependence}

Interdependence has been described as the connectedness among work roles (Morgeson \& Humphrey, 2006) and reflects the degree to which enactment depends on reciprocal interaction with others in order to accomplish work goals (Kiggundu, 1981). Thus, interdependence can be viewed as the extent to which performance is predicated or reliant on contingent social relationships (Dierdorff \& Morgeson, 2007). In a general sense, the degree to which a work role requires frequent interaction with individuals or groups can exacerbate work-related stress (Katz \& Kahn, 1978; Thompson, Kirk, \& Brown, 2006). This stress often stems from having to deal with the demands of individuals from multiple roles, which can deplete an individual's finite personal resources needed for successful enactment of his or her other roles (Edwards \& Rothbard, 2000). High levels of interpersonal interactions at work can also lead to "fatigue" that causes withdrawal from other personal relationships (Kanter, 1977).

Occupations with high levels of interdependence are more likely to necessitate boundary-spanning activities as well (Dierdorff \& Morgeson, 2007). In this case, to successfully meet the work role obligations, individuals must take on additional role activities beyond those of their own designated jobs. Important to behaviorbased antecedents of work-family conflict, participation in such boundary-spanning behavior has been shown to increase levels of work-family conflict (Burke, Weir, \& DuWors, 1980; Greenhaus $\&$ Beutell, 1985). Thus, for the reasons discussed above, we expected high levels of interaction with others to influence workfamily conflict.

Hypothesis 1: Increased interdependence is associated with higher levels of work-family conflict.

\section{Responsibility for Others}

Within the context of work roles, responsibility for others can include the level of accountability for aspects, such as work outcomes of other role holders, the quality of results produced by others, and the health or safety of other workers (Strong et al., 1999). Having responsibility for others has long been argued as a significant influence on work-related stress (Beehr \& Newman, 1978; Kahn, 1981). Even the inference of responsibility may lead to increased stress (Cobb, 1974; Riordan, Johnson, \& Thomas, 1991). Early work-family conflict research also found higher levels of conflict associated with managerial work (Kahn et al., 1964), which by definition requires higher levels of responsibility (Bhalla, Jones, \& Flynn, 1991).

Because family roles are likely to carry with them the responsibility for other individuals (i.e., other family members), working within an occupation that requires high levels of accountability for other workers could lead to a significant resource drain for persons in such work roles. Spillover theory argues that this drain can exhaust an individual's psychological and physiological resources to perform work and family roles (Eckenrode \& Gore, 1990). This exhaustion can increase work-family conflict (Aryee et al., 2005).
Following this logic and related research, we expected levels of responsibility for others within the work role to impact workfamily conflict.

Hypothesis 2: Increased responsibility for others is associated with higher levels of work-family conflict.

\section{Interpersonal Conflict}

Interpersonal conflict at work can range from minor disagreements among coworkers to physical assaults on others (Spector \& Jex, 1991). From the perspective of work role requirements, the amount of interpersonal conflict an individual encounters manifests in duties such as dealing with unpleasant, angry, or discourteous individuals, or even handling physical aggression (Strong et al., 1999). Prevalent interpersonal conflict can make work more stressful (Keenan \& Newton, 1985; Narayanan, Menon, \& Spector, 1999) and such stress increases frustration and tendencies to distance oneself from one's social environment (De Dreu \& Beersma, 2005).

Studies have also shown high levels of interpersonal conflict to correlate with exhaustion and job burnout (e.g., Brondolo et al., 1998; Frone, 2000; Leiter, 1991; Van Dierendonck, Schaufeli, \& Sixma, 1994). These related findings suggest that interpersonal conflict leads to exhaustion of energy. Stated another way, interpersonal conflict is likely to drain one's personal resources, which can exacerbate work-family conflict. Not only is interpersonal conflict likely to drain resources needed to deal with such conflict in other roles, the work behaviors associated with interpersonal conflict may clash with behaviors requisite to family roles. That is, work behaviors related to handling or engaging interpersonal conflict could exhibit spillover effects into the family role in which they may be inappropriate, thereby increasing levels of workfamily conflict (Zedeck, 1992). Considering this related research and the implications for resource drain and spillover, we expected levels of interpersonal conflict within the work role to impact work-family conflict.

Hypothesis 3: Increased interpersonal conflict is associated with higher levels of work-family conflict.

\section{Method}

\section{Databases}

General Social Survey (GSS). We used data collected by the GSS to capture levels of work-family conflict and several control variables. The GSS is a cumulative, nationally representative survey administered by the National Opinion Research Center at the University of Chicago. The GSS was conducted annually from 1972 to 1994 and biennially thereafter. The GSS is designed to examine trends in attitudes and behaviors in U.S. society. Participants are sampled with a national full-probability approach and surveyed with a structured, face-to-face interview lasting roughly 90 min. Response rates have ranged from $70 \%$ to $82 \%$ since 1975 Items to be included on the GSS are reviewed by over 150 social scientists prior to release, and question wording, context effects, and response scales are reviewed annually. To examine workfamily conflict, we specifically used a topical module of the 2002 GSS entitled "Quality of Working Life," developed by the Na- 
Table 1

Occupational and Incumbent Sample Sizes

\begin{tabular}{|c|c|c|c|c|}
\hline SOC code & SOC major group & $f$ & GSS occupation examples & $n$ \\
\hline $11-0000$ & Management occupations & 9 & General managers; financial managers; funeral directors & 220 \\
\hline $13-0000$ & Business and financial operations occupations & 6 & Accounts and auditors; management analysts & 59 \\
\hline $15-0000$ & Computer and mathematical occupations & 2 & Computer systems analysts; computer programmers & 36 \\
\hline $17-0000$ & Architecture and engineering occupations & 4 & Civil engineers; architects; surveyors & 28 \\
\hline $19-0000$ & Life, physical, and social science occupations & 3 & Economists; psychologists; geologists & 17 \\
\hline $21-0000$ & Community and social services occupations & 2 & Clergy; social workers; therapists & 30 \\
\hline $23-0000$ & Legal occupations & 2 & Lawyers; law clerks; stenographers & 18 \\
\hline $25-0000$ & Education, training, and library occupations & 7 & Librarians; curators; English teachers & 87 \\
\hline $27-0000$ & Arts, design, entertainment, sports, and media occupations & 8 & Actors; directors; designers; reporters & 38 \\
\hline $29-0000$ & Healthcare practitioners and technical occupations & 4 & Registered nurses; dentists; pharmacists & 47 \\
\hline $31-0000$ & Healthcare support occupations & 2 & Dental assistants; health aides; orderlies & 48 \\
\hline $33-0000$ & Protective service occupations & 5 & Firefighters; sheriffs; correctional officers & 34 \\
\hline $35-0000$ & Food preparation and serving related occupations & 5 & Cooks; waiters; kitchen workers & 76 \\
\hline $37-0000$ & Building and grounds cleaning and maintenance occupations & 4 & Groundskeepers; gardeners; janitors; maids & 47 \\
\hline $39-0000$ & Personal care and service occupations & 4 & Child care workers; hairdressers; cosmetologists & 42 \\
\hline 41-0000 & Sales and related occupations & 10 & Cashiers; real estate brokers; financial services sales & 134 \\
\hline 43-0000 & Office and administrative support & 21 & Bank tellers; expediters; hotel clerks; secretaries & 181 \\
\hline $45-0000$ & Farming, fishing, and forestry occupations & 1 & Farm workers; fishers; forestry workers & 7 \\
\hline $47-0000$ & Construction and extraction occupations & 7 & Electricians; sheet metal workers; carpenters; roofers & 71 \\
\hline 49-0000 & Installation, maintenance, and repair occupations & 6 & Automotive mechanics; millwrights; telephone repairers & 37 \\
\hline $51-0000$ & Production occupations & 7 & Assemblers; bakers; machinists; welders and cutters & 44 \\
\hline $53-0000$ & Transportation and material moving occupations & 7 & Bus drivers; air traffic controllers; taxicab drivers & 75 \\
\hline
\end{tabular}

Note. $\quad$ SOC $=$ Standard Occupational Classification; GSS $=$ General Social Survey; $f=$ frequency of occupations in group; $n=$ sample size.

tional Institute for Occupational Safety and Health. Questions focused on the nature of work and its effect on employees, including items on coworker and supervisor relationships, work-related stress, management-labor issues, and health. The response rate for this module was $70 \%$, with a total sample of 2,765 adults living in the United States.

$O * N E T$. To capture behavior-based antecedents of workfamily conflict, we used archival O*NET data. O*NET is a comprehensive database of occupational information (Dye \& Silver, 1999). O*NET data are representative of the national labor force, collected with a staged sampling process, and based on tens of thousands of surveyed incumbents. Sampling takes into account the broad business environment, the types and sizes of establishments that employ incumbents, and the number of individuals employed in the U.S. labor market. Respondents are chosen by a stratified random sampling in which randomly selected individuals from an establishment are based on the proportion of incumbents in the labor market that work at such establishments.

\section{Procedure}

The GSS asks respondents to indicate the kind of work they do, their job titles, and some of their main job duties. This information is then classified with U.S. Bureau of the Census occupation codes. These codes allowed the specific cross-referencing of GSS data to $\mathrm{O}^{*}$ NET information. Cross-referencing was conducted as sequential steps. First, we reviewed the U.S. Census occupation codes and associated occupational titles within the GSS sample. Second, a data set was created that included all GSS respondents with complete Census occupation codes and work-family conflict variables. This data set contained 1,770 GSS respondents. Third, the Census occupation codes and titles in the GSS data were matched by the study's authors to specific O*NET occupations. Cases where no clear matches were possible were excluded. Such cases were due to Census occupation codes being too broad or nondescript to be matched to a single O*NET occupation. This cross-referencing procedure resulted in a final usable sample of 1,367 individuals spanning 126 different occupations. ${ }^{2}$ In comparison with the Standard Occupational Classification system (SOC) of the U.S. Bureau of Labor Statistics, all major groupings for which O*NET data are collected were represented. Table 1 shows frequencies and sample sizes for the 126 occupations with respect to the SOC as well as examples of specific occupational titles.

\section{Measures}

Behavior-based antecedents. The three behavior-based sources were operationalized with $\mathrm{O} * \mathrm{NET}$ data, which are standardized to range from 1 to 100 to facilitate cross-occupational comparisons. Interdependence was assessed with three items rated on a 5-point importance scale. Items asked how important interactions are that require the respondent to "work with or contribute to a work group or team?"; "deal with external customers (as in retail sales) or the public in general (as in police work)?"; and "coordinate or lead others in accomplishing work activities (not as a supervisor or team leader)?"

The second behavior-based measure of responsibility for others was operationalized with two items rated on a 5-point scale (ranging from $1=$ no responsibility to $5=$ very high responsibility). The two items were "how responsible are you for work outcomes

\footnotetext{
${ }^{2}$ Differences in mean levels of work-family conflict between the full sample $(N=1,770)$ and the usable sample $(N=1,376)$ were not significant $(p=.39)$. In fact, none of the variables derived from the GSS differed significantly across the two samples $(p>.01)$.
} 
and results of other workers?" and "how responsible are you for the health and safety of other workers?" Finally, the third behavior-based measure of interpersonal conflict was operationalized with three items rated on a 5-point frequency scale (ranging from $1=$ never to $3=$ once a month, but not every week to $5=$ every day). Items were as follows, "how often are conflict situations a part of your current job?"; "how often is dealing with unpleasant, angry, or discourteous people a part of your current job?"; and "how often is dealing with violent or physically aggressive people a part of your current job?"

Confirmatory factor analysis verified the distinctiveness of these measures, as a three-factor model provided adequate fit (goodness of fit $[\mathrm{GFI}]=.96$, comparative fit index $[\mathrm{CFI}]=.94$, standardized root mean square residual $[\mathrm{SRMR}]=.05$, root mean square error of approximation [RMSEA] $=.08$ ) and significant improvement in fit over a one-factor model assessed with chi-square difference test $(p<.01)$.

Work-family conflict. The variable of work-family conflict was assessed with an item from the GSS asking "how often do the demands of your job interfere with your family life" (response scale ranged from $1=$ never to $4=$ often).

Control variables. Two sets of control variables from the GSS were used. The first set controlled for demographics: sex, age, and number of children 12 years and under. Some research suggests that men, older persons, and those with fewer young children may experience less work-family conflict (Eby, Casper, Lockwood, Bordeaux, \& Brinley, 2005; Gutek et al., 1991; Loerch, Russell, \& Rush, 1989; Prottas \& Thompson, 2006). The second set controlled for several time- and strain-based sources of work-family conflict, allowing a better depiction of hypothesized effects in relation to more extensively researched work-family conflict antecedents.

From available GSS data, two time-based antecedents were controlled: flexibility in work scheduling and time pressures, each assessed with a single item ("how hard is it to take time off during your work to take care of personal or family matters" and "I have enough time to get the job done"). Substantial research has shown increased schedule flexibility and decreased time pressures to be associated with less work-family conflict (e.g., Burke et al., 1980; Ford et al., 2007; Frone, Yardley, \& Markel, 1997; Gutek et al., 1991; Keith \& Schafer, 1980; Major, Klein, \& Ehrhart, 2002; Parasuraman, Pruohit, Godshalk, \& Beutell, 1996; Wallace, 1997). Three strain-based antecedents were also controlled: social support, role overload, and role clarity. Social support from peers and supervisors was assessed with three items (e.g., "my supervisor is helpful to me in getting the job done"), whereas role overload and role clarity were each assessed with single-item measures ("I have too much work to do everything well" and "on my job, I know exactly what is expected of me"). Research has shown increased role clarity and social support and decreased role overload to be associated with less work-family conflict (e.g., Burke, 1988; Carlson \& Perrewe, 1999; Erdwins, Buffardi, Casper, \& O'Brien, 2001; Goff et al., 1990; Jones \& Butler, 1980; Kopelman, Greenhaus, \& Connolly, 1983; Netemeyer et al., 1996).

As described above, several constructs were operationalized with single-item measures. Although single-item indicators could increase the likelihood of unreliability in measurement, we believe these potential risks are outweighed by making possible an expansive examination of work-family conflict (i.e., over 1,300 individ- uals working in 126 occupations). Further, the integrated archival data are derived from two well-established, nationally representative, and empirically developed databases. Lastly, assessing workfamily conflict with single-item measures is not uncommon (e.g, Rice, Frone, \& McFarlin, 1992; Voydanoff, 1988), and some have noted that criticisms of single-item indicators in general may be overestimated (Wanous \& Hudy, 2001).

\section{Analytical Strategy}

The integrated data set was hierarchical in nature, with individual-level data (GSS) nested within occupational-level data (O*NET). To appropriately address this structure, we used hierarchical linear modeling (HLM) to simultaneously model both within and between-group variance in work-family conflict (Bryk \& Raudenbush, 1992; Hofmann, 1997). HLM accounts for dependencies due to hierarchical structure and, thus, is more statistically appropriate than other techniques that assume independent observations (e.g., ordinary least squares regression). HLM was conducted in a staged approach using HLM 6 software (Raudenbush, Bryk, Cheong, \& Congdon, 2004).

The first stage estimated a "null model" to partition total variance in the criterion (i.e., work-family conflict) into withinoccupation and between-occupation components (Hofmann, 1997). Given significant between-occupation variance, the second stage introduced individual-level predictors in a randomcoefficient regression model (Level 1 analysis). All Level 1 variables were grand mean centered and, thus, the Level 1 intercept variance represents the between-occupation variance in workfamily conflict, adjusted for the Level 1 variables (Hofmann \& Gavin, 1998). Given significant between-occupation variance in the Level 1 intercepts, the last stage introduced Level 2 predictors in an intercepts-as-outcomes model. ${ }^{3}$ This final model addresses Hypotheses 1-3.

\section{Results}

Table 2 presents descriptive statistics and zero-order correlations for all individual- and occupation-level variables. Except for sex and role clarity, all individual-level variables were significantly related to work-family conflict $(p<.05)$, suggesting their value as controls. Null model results showed significant betweenoccupation variance in work-family conflict, $\tau_{00}=.09, \chi^{2}(125)=$ $247.04, p<.01$, intraclass coefficient (ICC) $=.09$. This indicates that $9 \%$ of the total variance in work-family conflict resides between occupations.

Table 3 presents results from the random-coefficient regression model. Several individual-level variables were significant, explaining $25 \%$ of the variance in work-family conflict. With regard to time-based antecedents, time pressures $\left(\gamma_{40}=.198, p<.01\right)$ and flexibility of scheduling $\left(\gamma_{50}=-.251, p<.01\right)$ explained significant variation in work-family conflict, indicating that as time demands increased (more time pressures and less schedule

\footnotetext{
${ }^{3}$ Because the Level 1 variables were grand mean centered, the Level 2 regression coefficients represent the occupation-level relationship between the Level 2 predictors (the three behavior-based sources) and work-family conflict, after controlling for the influence of the individual-level variables (time- and strain-based sources and demographic variables).
} 
Table 2

Descriptive Statistics and Zero-Order Correlations for All Variables

\begin{tabular}{|c|c|c|c|c|c|c|c|c|c|c|}
\hline Variable & $M$ & $S D$ & \multicolumn{8}{|c|}{ Variable } \\
\hline \multicolumn{11}{|c|}{ Individual level } \\
\hline & & & 1 & 2 & 3 & 4 & 5 & 6 & 7 & 8 \\
\hline 1. Work-family conflict & 2.77 & 0.99 & - & & & & & & & \\
\hline 2. Age & 40.83 & 12.98 & $-.09^{* *}$ & - & & & & & & \\
\hline 3. Sex & 0.55 & 0.50 & -.03 & -.01 & - & & & & & \\
\hline 4. Number of children & 0.48 & 0.89 & $.12^{* *}$ & $-.23^{* *}$ & $.07^{* *}$ & - & & & & \\
\hline 5. Time pressures & 1.79 & 0.88 & $.30^{* *}$ & .00 & .01 & -.02 & - & & & \\
\hline 6. Flexibility in schedule & 1.87 & 1.00 & $-.34^{* *}$ & $.08^{* *}$ & $-.07^{*}$ & -.03 & $-.23^{* *}$ & - & & \\
\hline 7. Social support & 1.67 & 0.63 & $-.12^{* *}$ & $.09^{* * *}$ & $.06^{*}$ & .01 & $-.33^{* *}$ & $.18^{* * *}$ & $(.91)$ & \\
\hline 8. Role overload & 2.79 & 0.73 & $.27^{* *}$ & -.04 & .04 & .02 & $.38^{* * *}$ & $.27^{* * *}$ & $.22^{* * *}$ & - \\
\hline 9. Role clarity & 1.63 & 0.63 & -.04 & $.05^{*}$ & $.05^{*}$ & .03 & $-.17^{* *}$ & -.03 & $.16^{* *}$ & $-.13^{* *}$ \\
\hline \multicolumn{11}{|c|}{ Occupational level } \\
\hline & & & 10 & 11 & 12 & & & & & \\
\hline 10. Interdependence & 61.89 & 22.01 & $(.86)$ & & & & & & & \\
\hline 11. Responsibility for others & 43.93 & 22.20 & $.74^{* *}$ & - & & & & & & \\
\hline 12. Interpersonal conflict & 34.61 & 15.66 & $.78^{* *}$ & $.61^{* *}$ & $(.87)$ & & & & & \\
\hline
\end{tabular}

Note. $\quad N=1,367$ for individual-level variables; $N=126$ for occupational-level variables; sex is coded as $0=$ male, $1=$ female; number of children $=$ number of children 12 years of age and under; values reversed to be consistent with directional hypotheses (e.g., higher values indicate greater levels of work-family conflict); where applicable, coefficient alphas are shown in parentheses.

${ }^{*} p \leq .05{ }^{* * *} p \leq .01$

Table 3

\section{Random-Coefficient Regression Model Results}

\begin{tabular}{lccr}
\hline \multicolumn{1}{c}{ Fixed effects } & Coefficient & $S E$ & $t$ ratio \\
\hline $\begin{array}{l}\text { Intercept, } \beta_{0} \\
\text { Intercept, } \gamma_{00}\end{array}$ & $2.782^{* * *}$ & .033 & 85.23 \\
\hline \multicolumn{4}{c}{ Demographic control variables } \\
Age, $\beta_{1}$ & & \\
$\quad$ Intercept, $\gamma_{10}$ & -.004 & .002 & -1.88 \\
$\begin{array}{l}\text { Sex, } \beta_{2} \\
\quad \text { Intercept, } \gamma_{20}\end{array}$ & -.090 & .057 & -1.57 \\
$\begin{array}{l}\text { Number of children, } \beta_{3} \\
\text { Intercept, } \gamma_{30}\end{array}$ & $.131^{* * *}$ & .029 & 4.47 \\
\hline
\end{tabular}

Time-based conflict

Time pressures, $\beta_{4}$ Intercept, $\gamma_{40}$

Flexibility in schedule, $\beta_{5}$ Intercept, $\gamma_{50}$

\begin{tabular}{ccc}
$.198^{* * *}$ & .029 & 6.74 \\
$-.251^{* * *}$ & .029 & -8.56 \\
\hline
\end{tabular}

Strain-based conflict

\begin{tabular}{lccc} 
Social support, $\beta_{6}$ & & & \\
$\quad$ Intercept, $\gamma_{60}$ & -.023 & .041 & -0.58 \\
Role overload, $\beta_{7}$ & & & \\
$\quad$ Intercept, $\gamma_{70}$ & $.167^{* *}$ & .040 & 4.14 \\
$\begin{array}{l}\text { Role clarity, } \beta_{8} \\
\text { Intercept, } \gamma_{80}\end{array}$ & -.021 & .038 & -0.57 \\
\hline
\end{tabular}

Note. $S E=$ robust standard error.

${ }^{*} p \leq .05 .{ }^{* *} p \leq .01$ flexibility), work-family conflict increased. As for strain-based antecedents, only role overload was significantly associated with work-family conflict $\left(\gamma_{70}=.167, p<.01\right)$, with higher levels of overload associated with greater work-family conflict. Significant between-occupation variance in the intercepts remained, $\tau_{00}=.04$, $\chi^{2}(41)=73.30, p<.01$, after controlling for these variables, which is a necessary condition for testing higher level relationships (Hypotheses 1-3).

Table 4 presents results from the intercepts-as-outcomes model introducing occupational-level predictors to test study hypotheses. Both interdependence $\left(\gamma_{01}=.005, p<.01\right)$ and responsibility for others $\left(\gamma_{02}=.004, p<.05\right)$ explained significant betweenoccupation variance in work-family conflict, after controlling for individual-level variables. Higher levels of interdependence and responsibility for others were associated with greater work-family conflict, supporting Hypotheses 1 and 2. Interpersonal conflict was unrelated to work-family conflict $(p=.13)$, failing to support Hypothesis 3. Overall, the behavior-based antecedents explained $48 \%$ of the variance between occupations in work-family conflict.

\section{Discussion}

One general implication of the current study is the empirical support for previous theoretical work claiming that knowing someone's occupation provides meaningful contextual information regarding his or her work (Johns, 2006). Across 126 occupations, our results show that simply knowing the occupations in which individuals work accounts for significant variance in their reported levels of work-family conflict. Beyond differences attributable to occupation, our findings also indicate that specific occupational 
Table 4

Intercepts-as-Outcomes Model Results

\begin{tabular}{|c|c|c|c|}
\hline Fixed effects & Coefficient & $S E$ & $t$ ratio \\
\hline \multicolumn{4}{|c|}{ Behavior-based conflict } \\
\hline \multicolumn{4}{|l|}{ Intercept, $\beta_{0}$} \\
\hline Intercept, $\gamma_{00}$ & $3.094^{* *}$ & .064 & 48.07 \\
\hline Interdependence, $\gamma_{01}$ & $.005^{* *}$ & .002 & 2.74 \\
\hline Responsibility for others, $\gamma_{02}$ & $.004^{*}$ & .002 & 2.43 \\
\hline Interpersonal conflict, $\gamma_{03}$ & -.005 & .003 & -1.53 \\
\hline \multicolumn{4}{|c|}{ Demographic control variables } \\
\hline \multicolumn{4}{|l|}{ Age, $\beta_{1}$} \\
\hline Intercept, $\gamma_{10}$ & $-.004^{*}$ & .002 & -1.96 \\
\hline \multicolumn{4}{|l|}{ Sex, $\beta_{2}$} \\
\hline Intercept, $\gamma_{20}$ & -.102 & .059 & -1.71 \\
\hline \multicolumn{4}{|l|}{ Number of children, $\beta_{3}$} \\
\hline Intercept, $\gamma_{30}$ & $.137^{* *}$ & .030 & 4.55 \\
\hline
\end{tabular}

Time-based conflict

Time pressures, $\beta_{4}$

Intercept, $\gamma$

Flexibility in schedule, $\beta_{5}$

Intercept, $\gamma_{50}$

$$
.194^{* * *}
$$

$-.249^{*}$

.030

$-8.36$

Strain-based conflict

Social support, $\beta_{6}$ Intercept, $\gamma_{60}$

Role overload, $\beta$ Intercept, $\gamma_{70}$

Role clarity, $\beta_{8}$

Intercept, $\gamma_{80}$ $-.015$

$$
.170^{* * *}
$$
$-.029$ .038

Note. $S E=$ robust standard error.

${ }^{*} p \leq .05 .{ }^{* * *} p \leq .01$

features explain almost half of the between-occupation variance in work-family conflict. It is important to note that our multilevel analyses controlled for several demographic, time-, and strainbased variables known to influence work-family conflict. In a broad sense, then, results suggest that delineating behavior-based sources of work-family conflict with work role requirements is theoretically meaningful and a valuable approach for future workfamily conflict research.

Of the three behavior-based sources examined, interdependence and responsibility for others appear predictive of work-family conflict. Here, individuals working in occupations that necessitate substantial interactions with other individuals or other work roles in order to meet their own work role obligations (i.e., getting their jobs done) are also those more likely to report greater work-family conflict. This finding is congruent with the proposition that high levels of interaction at work may lead to increased fatigue and depletion of personal resources needed to fulfill family role obligations. Similarly, individuals working in occupations that require greater responsibility for others appear more likely to experience work-family conflict. Taken together, these findings strongly suggest that the greater psychosocial demands associated with work roles entailing increased interpersonal relationships are salient factors influencing one's experience of work-family conflict.

The effects of these two behavior-based antecedents can be further illustrated by examining differences between the average levels of work-family conflict across occupations. For example, three sample occupations associated with the highest levels of work-family conflict (more than $1 S D$ above the mean) were police detectives, firefighters, and family and general practitioners. These occupations also require high levels of interdependence and/or responsibility for others: police detectives had scores of 75.3 and 50.5; firefighters had scores of 82.6 and 73.5; and family and general practitioners had scores of 83.0 and 69.0 for interdependence and responsibility for others, respectively (see Table 2 for overall means). By comparison, sample occupations with the lowest levels of work-family conflict included taxi drivers, insurance adjusters and examiners, and tellers. Scores for interdependence and responsibility for others were similarly lower: 58.3 and 58.5 for taxi drivers; 58.0 and 28.5 for insurance adjusters and examiners; and, 62.0 and 40.0 for tellers.

However, findings fall short of supporting our hypothesis that increased interpersonal conflict is associated with higher levels of work-family conflict. The lack of significant influence could stem from the nature of the occupations within the study sample, as the mean for this variable was relatively lower and had less variance than other variables. Another possible explanation is that the impact of interpersonal conflict may be more in the eye of the role holder and thus be influenced more by individual differences (e.g., resiliency), especially when compared with the other behaviorbased antecedents. That is, interdependence and responsibility for others may require clear behavioral expectations within work roles and thus be more clearly linked to occupational differences than work role requirements necessitating interpersonal conflict.

It is interesting to note that previous work-family conflict studies have tended to use variables not directly linked to the actual behavioral requirements or duties of the work role. Instead, variables such as employment relationship (e.g., self-employed, family business, telecommuting), autonomy, prestige, or skill variety are generally chosen (e.g., Byron, 2005; Eby et al., 2005; Prottas \& Thompson, 2006). Perhaps the lack of attention to behavior-based sources of work-family conflict has been due to the difficulty associated with where and how to begin empirical examination, especially considering the countless varieties of behavior in which individuals engage while performing their jobs. As Casper, Eby, Bordeaux, Lockwood, and Lambert (2007) observed, even in the broader work-family literature, occupational information is inconsistently reported. Our study specifically highlights the value in relying on information gleaned from systematic work analysis. Work analysis provides rather robust descriptions of work behavior and, in the case of $\mathrm{O}^{*} \mathrm{NET}$, a parsimonious and taxonomic approach that uses a common descriptive language. Importantly, such data attributes also allow for meaningful comparisons across different occupations.

Using work role requirements to study behavior-based sources of work-family conflict has practical implications as well. If the context of particular occupations requires certain role behaviors that are known to be associated with work-family conflict, this information can be readily accessible for a number of interventions. For example, persons and organizations could use such information for career or vocational planning purposes, as realistic job previews during recruitment efforts, or as training material for inclusion in socialization or orientation programs (Zahrly \& Tosi, 1989). The practical value of this approach becomes quite salient when one considers that the consequences of work-family conflict impact both individuals (e.g., physical health, satisfaction, stress) 
and organizations (e.g., absenteeism, commitment, turnover) in rather significant ways (Eby et al., 2005). However, our findings further indicate that although work-family conflict differences can be attributed to occupational membership, it is the particular features of occupations that account for much of this variance. Thus, interventions may reap additional benefits if the developmental focus is turned more toward specific work role requirements than merely to what broad occupations are under consideration.

\section{Limitations}

Our study is not without limitations, and several warrant specific mention. In selecting control variables we were bound by items included in the GSS. Although we controlled for several time- and strain-based factors known to influence work-family conflict, other potentially important variables could not be assessed. For example, individual-level factors such as role salience, selfmonitoring, and neuroticism have been shown to predict workfamily conflict as have organizational-level variables such as the use of work-life programs (Eby et al., 2005). Moreover, the effects of behavior-based antecedents could be moderated by the extent to which work and family roles are segmented or integrated (Ashforth, Kreiner, \& Fugate, 2000). Finally, some constructs were assessed with single-item measures, which may lack reliability. Multiple-item scales exist for many of the study's variables, including work-family conflict (e.g., Carlson et al., 2000). Despite these potential limitations, using archival data did allow for broadreaching tests largely untenable in typical research designs. Nonetheless, our findings should be interpreted in light of such measurement conditions.

Our examinations of work-family conflict clearly focused on the work role as it conflicts with the family role rather than on family as it interferes with work. These two directions are believed to be related, yet distinct, concepts (O'Driscoll et al., 1992; Kossek \& Ozeki, 1998). Relevant to the behavior-based sources we examined, meta-analytic work indicates that antecedents from the work domain tend to associate more with work-to-family than family-to-work conflict (Byron, 2005). The GSS module includes an item assessing the extent to which family interferes with work; to be thorough, we conducted supplemental analyses using this criterion. As one would expect, between-occupation differences on this variable were quite small (i.e., less than $2 \%$ ). An investigation of behavior-based sources of family-to-work conflict was beyond the scope of our study. Further, archival data did not provide behavior-based measures from the family domain. However, this supplemental test may increase confidence in our other findings, as these two directionally distinct conflict items resulted in dissimilar occupational findings for work-family conflict.

\section{Conclusion}

The work-family literature has seen a wide proliferation of studies over the past two decades, with significant theoretical and empirical inroads. Given greatest emphasis in this literature are individual-level predictors from time- and strain-based sources. The field has gained much from such research. However, additional empirical work is clearly needed with regard to behaviorbased sources. Such needs were recognized more than 30 years ago by Greenhaus and Beutell (1985) in their seminal article on work- family conflict but have gone largely unanswered. It is our hope that this study will begin to turn increased attention toward this neglected area of work-family conflict research.

\section{References}

Aryee, S. (1992). Career orientations, perceptions of rewarded activity, and career strategies among industrial R \& D professionals. Journal of Engineering and Technology Management, 9, 61-82.

Aryee, S., Srinivas, E. S., \& Tan, H. H. (2005). Rhythms of life: Antecedents and outcomes of work-family balance in employed parents. Journal of Applied Psychology, 90, 132-146.

Ashforth, B. E., Kreiner, G. E., \& Fugate, M. (2000). All in a day's work: Boundaries and micro role transitions. Academy of Management Review, 25, 472-491.

Bacharach, S. B., Bamberger, P., \& Conely, S. (1991). Work-home conflict among nurses and engineers: Mediating the impact of stress on burnout and satisfaction at work. Journal of Organizational Behavior, $12,39-63$.

Bartolome, F., \& Evans, P. A. L. (1980). Must success cost so much? Harvard Business Review, 58, 137-148.

Bedeian, A. G., Burke, B. G., \& Moffett, R. G. (1988). Outcomes of work-family conflict among married male and female professionals. Journal of Management, 14, 475-491.

Beehr, T. A. (1995). Psychological stress in the workplace. London: Routledge.

Beehr, T. A., \& Newman, J. E. (1978). Job stress, employee health, and organizational effectiveness: A facet analysis, model and literature review. Personnel Psychology, 31, 665-699.

Bhalla, S., Jones, B., \& Flynn, D. M. (1991). Role stress among Canadian white-collar workers. Work and Stress, 4, 289-299.

Biddle, B. J. (1979). Role theory: Expectations, identities, and behaviors. New York: Academic Press.

Boyar, S. L., Maertz, C. P., Pearson, A., \& Keough, S. M. (2003). Work-family conflict: A model of linkages between work and family domain variables and turnover intentions. Journal of Managerial Issues, 15, 175-190.

Brondolo, E., Masheb, R., Stores, J., Stockhammer, T., Tunick, W., Melhado, E., Karlin, W. A., Schwartz, J., Harburg, E., \& Contrada, R. J. (1998). Anger-related traits and response to interpersonal conflict among New York City traffic agents. Journal of Applied Social Psychology, 28, 2089-2118.

Bryk, A. S., \& Raudenbush, S. W. (1992). Hierarchical linear models. Newbury Park, CA: Sage.

Burke, R. J. (1988). Some antecedents and consequences of work-family conflict. Journal of Social Behavior and Personality, 3, 287-302.

Burke, R. J., Weir, T., \& DuWors, R. E., Jr. (1980). Work demands on administrators and spouse well-being. Human Relations, 33, 253-278.

Byron (2005). A meta-analytic review of work-family conflict and its antecedents. Journal of Vocational Behavior, 67, 169-198.

Carlson, D. S., \& Frone, M. R. (2003). Relation of behavioral and psychological involvement to a new four-factor conceptualization of workfamily interference. Journal of Business and Psychology, 17, 515-535.

Carlson, D. S., Kacmar, K. M., \& Williams, L. J. (2000). Construction and initial validation of a multidimensional measure of work-family conflict. Journal of Vocational Behavior, 56, 249-276.

Carlson, D. S., \& Perrewe, P. L. (1999). The role of social support in the stressor-strain relationship: An examination of work-family conflict. Journal of Management, 25, 513-540.

Casper, W. J., Eby, L. T., Bordeaux, C., Lockwood, A., \& Lambert, D. (2007). A review of research methods in IO/OB work-family research. Journal of Applied Psychology, 92, 28-43.

Cobb, S. (1974). Physiologic changes in men whose jobs were abolished. Journal of Psychosomatic Research, 18, 245-258. 
De Dreu, C. K. W., \& Beersma, B. (2005). Conflict in organizations: Beyond effectiveness and performance. European Journal of Work and Organizational Psychology, 14, 105-117.

Dierdorff, E. C., \& Morgeson, F. P. (2007). Consensus in work role requirements: The influence of discrete occupational context on role expectations. Journal of Applied Psychology, 92, 1228-1241.

Dunnette, M. D. (1999). Introduction. In N. G. Peterson, M. D. Mumford, W. C. Borman, P. R. Jeanneret, \& E. A. Fleishman (Eds.), An occupational informational system for the 21st century: The development of $O * N E T$ (pp. 3-7). Washington, DC: American Psychological Association.

Dye, D., \& Silver, M. (1999). The Origins of O*NET. In N. G. Peterson, M. D. Mumford, W. C. Borman, P. R. Jeanneret, \& E. A. Fleishman (Eds.), An occupational informational system for the 21st century: The development of $O^{*} N E T$ (pp. 9-19). Washington, DC: American Psychological Association.

Eby, L. T., Casper, W. J., Lockwood, A., Bordeaux, C., \& Brinley, A. (2005). A twenty-year retrospective on work and family research in IO/OB: A review of the literature. Journal of Vocational Behavior, 66, 124-197.

Eckenrode, J., \& Gore, S. (1990). Stress between work and family. New York: Plenum Press.

Edwards, J. R., \& Rothbard, N. P. (2000). Mechanisms linking work and family: Specifying the relationships between work and family constructs. Academy of Management Review, 25, 178-199.

Erdwins, C. J., Buffardi, L. C., Casper, W. J., \& O’Brien, A. S. (2001). The relationship of women's role strain to social support, role satisfaction, and self-efficacy. Family Relations: Interdisciplinary Journal of Applied Family Studies, 50, 230-238.

Evans, G. W., Johansson, G., \& Carrere, S. (1994). Psychological factors and the physical environment: Inter-relations in the workplace. In C. N. Cooper, \& I. T. Roberston (Eds.), International review of industrial and organizational psychology (Vol. 9, pp. 1-29). Chichester, United Kingdom: Wiley.

Evans, P., \& Bartolome, F. (1984). The changing pictures of the relationship between career and family. Journal of Occupational Behavior, 5 , $9-21$.

Ford, M. T., Heinen, B. A., \& Langkamer, K. L. (2007). Work and family satisfaction and conflict: A meta-analysis of cross-domain relations. Journal of Applied Psychology, 92, 57-80.

French, J. R., \& Kahn, R. L. (1962). A programmed approach to studying the industrial environment and mental health. Journal of Social Issues, $18,1-47$

Frone, M. R. (2000). Work-family conflict and employee psychiatric disorders: The National Comorbidity Survey. Journal of Applied Psychology, 85, 888-895.

Frone, M. R., Russell, M., \& Cooper, M. L. (1992). Antecedents and outcomes of work-family conflict: Testing a model of the work-family interface. Journal of Applied Psychology, 77, 65-78.

Frone, M. R., Yardley, J. K., \& Markel, K. S. (1997). Developing and testing an integrative model of the work-family interface. Journal of Vocational Behavior, 50, 145-167.

Frye, K., \& Breaugh, J. A. (2004). Family-friendly policies, supervisor support, work-family conflict, family-work conflict, and satisfaction. Journal of Business and Psychology, 19, 197-220.

Goff, S. J., Mount, M. K., \& Jamison, R. L. (1990). Employer supported childcare, work/family conflict, and absenteeism: A field study. Personnel Psychology, 43, 793-809.

Greenhaus, J. H., Bedeian, A. G., \& Mossholder, K. W. (1987). Work experiences, job performance, and feelings of personal and family wellbeing. Journal of Vocational Behavior, 31, 200-215.

Greenhaus, J. H., \& Beutell, N. J. (1985). Sources of conflict between work and family roles. Academy of Management Review, 10, 76-88.

Gutek, B. A., Searle, S., \& Klepa, L. (1991). Rational versus gender role expectations for work-family conflict. Journal of Applied Psychology, $76,560-568$.

Hofmann, D. A. (1997). An overview of the logic and rationale of hierarchical linear models. Journal of Management, 23, 723-744.

Hofmann, D. A., \& Gavin, M. B. (1998). Centering decisions in hierarchical linear models: Implications for research in organizations. Journal of Management, 24, 623-641.

Johns, G. (2006). The essential impact of context on organizational behavior. Academy of Management Review, 31, 386-408.

Jones, A. P., \& Butler, M. C. (1980). A role transition approach to the stresses of organizational-induced family role disruption. Journal of Marriage and the Family, 42, 367-376.

Kahn, R. L. (1981). Work and health. New York: Wiley.

Kahn, R. L., Wolfe, D. M., Quinn, R. P., Snoek, J. D., \& Rosenthal, R. A. (1964). Organizational stress: Studies in role conflict and ambiguity. New York: Wiley.

Kanter, R. M. (1977). Men and women of the corporation. New York: Basic Books.

Katz, D., \& Kahn, R. L. (1978). The social psychology of organizations (2nd ed.). New York: Wiley.

Keenan, A., \& Newton, T. J. (1985). Stressful events, stressors, and psychological strains in young professional engineers. Journal of Occupational Behavior, 6, 151-156.

Keith, P. M., \& Schafer, R. B. (1980). Role strain in two-job families. Family Relations, 29, 483-488.

Kiggundu, M. (1981). Task interdependence and the theory of job design. Academy of Management Review, 6, 499-508.

Kopelman, R. E., Greenhaus, J. H., \& Connolly, T. R. (1983). A model of work, family, and interrole conflict: A construct validation study. Organizational Behavior and Human Performance, 32, 198-215.

Kossek, E. E., Lautsch, B. A., \& Eaton, S. C. (2005). Flexibility enactment theory: Implications of flexibility type, control, and boundary management for work-family effectiveness. In E. E. Kossek \& S. J. Lambert' (Eds.), Work and life integration: Organizational, cultural, and individual perspectives (pp. 243-261). Mahwah, NJ: Erlbaum.

Kossek, E. E., \& Ozeki, C. (1998). Work-family conflict, policies, and the job-life satisfaction relationship: A review and directions for organizational behavior-human resources research. Journal of Applied Psychology, 83, 139-149.

Leiter, M. P. (1991). Coping patterns as predictors of burnout: The functions of control and escapist coping patterns. Journal of Organizational Behavior, 12, 123-144.

Loerch, K. J., Russell, J. E. A., \& Rush, M. C. (1989). The relationship among family domain variables and work-family conflict for men and women. Journal of Vocational Behavior, 35, 288-308.

Major, V. S., Klein, K. J., \& Ehrhart, M. G. (2002). Work time, work interference with family, and employee distress. Journal of Applied Psychology, 87, 427-436.

McGrath, J. E. (1976). Stress and behavior in organizations. In M. D. Dunnette (Ed.), Handbook of industrial and organizational psychology. Chicago: Rand McNally.

Morgeson, F. P., \& Humphrey, S. E. (2006). The Work Design Questionnaire (WDQ): Developing and validating a comprehensive measure for assessing job design and the nature of work. Journal of Applied Psychology, 91, 1321-1339.

Narayanan, L., Menon, S., \& Spector, P. E. (1999). Stress in the workplace: A Comparison of gender and occupations. Journal of Organizational Behavior, 20, 63-73.

Netemeyer, R. G., Boles, J. S., \& McMurrian, R. (1996). Development and validation of work-family conflict and family-work scales. Journal of Applied Psychology, 18, 400-410.

O'Driscoll, M., Brough, P., \& Kalliath, T. (2006). Work-family conflict and facilitation. In F. Jones, R. J. Burke and M. Westman (Eds.) 
Work-life balance: A psychological perspective (pp. 117-142). Hove, United Kingdom: Psychology Press.

O’Driscoll, M. P., Ilgen, D. R., \& Hildreth, K. (1992). Time devoted to job and off-job activities, interrole conflict and affective experiences. Journal of Applied Psychology, 77, 272-279.

Olson-Buchanan, J., \& Boswell, W. (2006). Blurring boundaries: Correlates of integration and segmentation between work and non-work. Journal of Vocational Behavior, 68, 432-445.

Parasuraman, S., Pruohit, Y. S., Godshalk, V. M., \& Beutell, N. J. (1996). Work and family variables, entrepreneurial career success, and psychological well-being. Journal of Vocational Behavior, 48, 275-300.

Pleck, J. H., Staines, G. L., \& Lang, L. (1980). Conflicts between work and family life. Monthly Labor Review, 103, 29-32.

Prottas, D. J., \& Thompson, C. A. (2006). Stress, satisfaction, and the work-family interface: A comparison of self-employed business owners, independents, and organizational employees, Journal of Occupational Health Psychology, 11, 366-378.

Raudenbush, S. W., Bryk, A. S., Cheong, Y. F., \& Congdon, R. (2004). HLM 6: Hierarchical linear and nonlinear modeling. Lincolnwood, IL: Scientific Software International.

Rice, R. W., Frone, M. R., \& McFarlin, D. B. (1992). Work-nonwork conflict and the perceived quality of life. Journal of Organizational Behavior, 13, 155-168.

Riordan, C. A., Johnson, G. D., \& Thomas, J. S. (1991). Personality and stress at sea. Journal of Social Behavior and Personality, 6, 391-409.

Shaw, J. B., \& Riskind, J. H. (1983). Predicting job stress using data from the PAQ. Journal of Applied Psychology, 68, 253-261.

Spector, P. E., \& Jex, S. M. (1991). Relations of job characteristics from multiple data sources with employee affect, absence, turnover intentions, and health. Journal of Applied Psychology, 76, 46-53.

Strong, M. H., Jeanneret, P. R., McPhail, S. M., Blakley, B. R., \& D'Egidio, E. L. (1999). Work context: Taxonomy and measurement of the work environment. In N. G. Peterson, M. D. Mumford, W. C. Borman, P. R. Jeanneret, \& E. A. Fleishman (Eds.), An occupational information system for the 21st century: The development of the $O * N E T$ (pp. 127-145). Washington, DC: American Psychological Association.

Thomas, L. T., \& Ganster, D. C. (1995). Impact of family-supportive work variables on work-family conflict and strain: A control perspective. Journal of Applied Psychology, 80, 6-15.

Thompson, B. M., Kirk, A., \& Brown, D. (2006). Sources of stress in policewomen: A three-factor model. International Journal of Stress Management, 13, 309-328.

Van Dierendonck, D. Schaufeli, W. B., \& Sixma, H. J. (1994). Burnout among general practitioners: A perspective from equity theory. Journal of Social and Clinical Psychology, 13, 86-100.

Voydanoff, P. (1988). Work role characteristics, family structure demands, and work/family conflict. Journal of Marriage and the Family, 50, $749-761$.

Wallace, J. (1997). It's about time: A study of hours worked and work spillover among law firm lawyers. Journal of Vocational Behavior, 50 227-248.

Wanous, J. P., \& Hudy, M. J. (2001). Single-item reliability: A replication and extension. Organizational Research Methods, 4, 361-375.

Warren, J. A., \& Johnson, P. J. (1995). The impact of workplace support on work-family role strain. Family Relations: Journal of Applied Family \& Child Studies, 44, 163-169.

Zahrly, J., \& Tosi, H. (1989). The differential effect of organizational induction process on early work role adjustment. Journal of Organizational Behavior, 10, 59-74.

Zedeck, S. (1992). Introduction: Exploring the domain of work and family concerns. In S. Zedeck (Ed.), Work, families and organizations (pp. 1-32). San Francisco: Jossey-Bass.

Zedeck, S., \& Mosier, K. L. (1990). Work in the family and employing organization. American Psychologist, 45, 240-251. 